Article

\title{
Tamar Yoseloff as Ekphrasist, and Her Hidden Sweetheart: 'I Took His Heart, Placed It/in an Ivory Case $^{\prime+}$
}

\author{
Antony Huen 1 \\ Department of English and Related Literature, University of York, York YO10 5DD, UK; ph813@york.ac.uk \\ + This article is the expanded version of a conference paper presented at the Oxford English Graduate \\ Conference, 1 June 2018.
}

Received: 15 March 2019; Accepted: 12 April 2019; Published: 16 April 2019

\begin{abstract}
This article investigates Tamar Yoseloff's different engagements with the visual arts in her ekphrastic poems by focusing on her first collection Sweetheart (1998). There are many critical studies about the poetic ekphrastic tradition, but there is rarely an in-depth investigation into a poet's dedication to ekphrasis. This article suggests that Tamar Yoseloff's dedication to ekphrasis is traceable to her earliest work. With a close analysis of three poems from Sweetheart-'The Two Fridas', 'The Arnolfini Marriage' and 'The Visible Man', I argue that the book is a sustained exploration of the autobiographical and biographical enigmas represented in visual artworks and artefacts, as well as our identification with these enigmas. It is hoped that this article could initiate a discussion about the tradition of poets dedicated to ekphrasis being as long as the tradition of modern ekphrasis.
\end{abstract}

Keywords: poetry; ekphrasis; visual arts; Wittgenstein; Freud; psychoanalysis

\section{Background}

Tamar Yoseloff, born in New Jersey in 1965 and based in London since 1987, is a poet dedicated to the visual arts in her writing and in her teaching of creative writing as a freelance tutor. She started her online blog Invective against Swans in September 2010, and as she states in a post of the same name (13 December 2013), the blog has been exploring 'the intersections between poetry and art' (Yoseloff 2013). It is also the 'intersections' between poetry and the visual arts Yoseloff returns to exploring in her poetry.

Yoseloff's first full-length collection is Sweetheart (1998), and many of its poems are included in $A$ Formula for Night: New and Selected Poems (Yoseloff 2015). Across her career, she has been consistently writing about a vast range of plastic arts, including Dutch painting, abstract expressionist art, conceptual sculpture and photographs. Anticipating her following publications, Sweetheart is fascinatingly a personal art gallery in the form of a book. It figuratively displays the controversial cover image of The Beatles' Yesterday and Today, maps used in a history classroom and diagrams in a biology textbook, Henry Moore's sculpture King and Queen, the 1940s film Now, Voyager, which takes its name from a poem by Walt Whitman, a miniature man called 'The Visible Man', and many photographs and paintings.

For the purpose of this case study of Yoseloff's Sweetheart, I will call her an ekphrasist as writer with a lifelong investment in ekphrasis, the ancient Greek term we have appropriated to refer to, as the online Oxford English Dictionary (OED) tells us, 'a literary device', where a work of visual art is 'described in detail' (OED Online 2019a). There have been many critical attempts at defining ekphrasis in the way the online OED does, from James A. W. Heffernan's Museum of Words (1993) to Stephen Cheeke's Writing for Art: The Aesthetics of Ekphrasis (2008) as well as other thematic studies of ekphrasis since the 2000s. To give a fuller investigation into Yoseloff's diverse poetic engagements with the visual arts, I want to, however, use the term in a broader sense. In Twentieth-Century Poetry and the Visual Arts, 
Elizabeth Bergmann Loizeaux recovers 'the classical sense of ekphrasis as the description of a process', suggesting that it 'can be found in Homer's description of Achilles' shield, which is framed by and periodically reverts to Hephaestos' making of it' (Loizeaux 2008, p. 13). Loizeaux goes so far as to call for attention to modern poetic 'ekphrases of creation', in particular, 'the process and challenges' of creating art (Loizeaux 2008, p. 13). In this study, I want to continue with Loizeaux's recovery of such an enlarged sense of modern poetic ekphrasis, which could address both the artwork itself and the creation of it. Like many of her poetic predecessors such as Frank O' Hara (as in 'Why I Am Not a Painter') and W. S. Graham (as in 'The Thermal Stair's'), Yoseloff has, I want to suggest, described both the visual artworks and the creation of them.

Indeed, there have been many poets who consistently describe the reception and creation of art and with a deep investment in the visual arts. Tamar Yoseloff is responsible for the current continuation and development of the ekphrastic tradition and has written poems responding to or invoking D. G. Rossetti, Frank O'Hara and W. S. Graham, who could all be called ekphrasists. D. G. Rossetti is known as an artist-poet, but he could as well be called an artist-ekphrasist, responding to his own paintings and in the case of 'The Blessed Damozel', creating a painting of the same name of the poem. With the new term ekphrasist, controversial as it might be, and with the focus on a contemporary ekphrasist, I hope to initiate a discussion about the tradition of poets dedicated to ekphrasis being as long as the tradition of modern ekphrasis.

\section{Tamar Yoseloff as Ekphrasist}

I want to suggest that Tamar Yoseloff is representative of a contemporary poet dedicated to ekphrasis as well as the 'intersections' between poetry and the visual arts. As a follow-up to the expansive curation in her first collection Sweetheart, Barnard's Star (2004) includes a group of poems about church painting and sculpture. Her third book Fetch (2007) includes the long title poem of the collaborative artist's book Marks (2007), responding to a group of sketches by the artist Linda Karshan. The title sequence of The City with Horns (2011) recreates the violent but loving relationship between the abstract expressionists Jackson Pollock and Lee Krasner, and their visions of the close relations between painting and life. Besides Marks, Yoseloff has co-published a few other collaborative editions with visual artists. Formerly (2012), for example, is a pocket-sized pamphlet containing pairs of Yoseloff's poems and Vici MacDonald's photographs of unexpected parts of London. The pamphlet was shortlisted for the Ted Hughes Award in the same year.

Yoseloff has been a fully-fledged ekphrasist, with ekphrasis being a key model and theme of her poetry. In 'Studies for a Portrait of a Young Woman, Delft' from Barnard's Star and 'Portrait of a Couple Looking at a Turner Landscape' from Fetch, Yoseloff alludes to what could be a pictorial portrait by Johannes Vermeer and a landscape painting by J. M. W. Turner. Yoseloff, nevertheless, also challenges the common role of an ekphrasist as a viewer by framing a poem as 'Portrait' and stanzas as 'Studies for a Portrait', and simultaneously reframing the notional or actual paintings in question. 'Cryptographer' from The City with Horns, based on Cy Twombly's Quattro Stagioni: Inverno (1993-1995)1, begins by recreating the artist's vision of his scribbly art: 'I string together little fables/in a language no one understands' (Yoseloff 2011, p. 5). Alluding to the traditions of cryptography, 'fables' and even embroidery, as in 'string', Yoseloff brings together multiple artistic forms and reflects on 'language' as an agent of both communication and encryption. With its irregular fourteen-line sonnets, Formerly distinctly appropriates a traditional poetic structure for the recreations of a past and memory evoked by the photographs of derelict places across London.

1 See an image of the painting here: https://www.tate.org.uk/art/artworks/twombly-quattro-stagioni-inverno-t07890. 


\section{The Hidden Sweetheart}

With her first collection Sweetheart (1998), Yoseloff has, in fact, already made a career-defining statement about her being a visual artwork and artefact curator in verse by responding to and invoking the largest range of visual images in her career. 'Cryptographer' from The City with Horns clearly marks Yoseloff's fascination with the creation of a language which 'no one understands'. By studying mainly three poems from Sweetheart-'The Two Fridas', 'The Arnoflini Marriage' and 'The Visible Man', I want to suggest that the book anticipates her future work, including 'Cryptographer', by being a sustained investigation into the uses of images of the body and clothing in art to create enigmatic autobiographical and biographical representations.

\section{1. 'The Two Fridas': 'I Used to Wear My Heart on My Sleeve'}

With 'The Two Fridas' from Sweetheart (1998), Yoseloff is responsible for a new, largely female sub-tradition of ekphrastic writing based on the art and biography of the Mexican painter Frida Kahlo. This is traceable to Sujata Bhatt's The Stinking Rose, recreating the self-mirroring effect inherent in Kahlo's painting ('My parrots long for yours, Frida, and they long for you') and Bhatt's own identification with the blackness in the art of Kahlo and the painter herself ('to pull out every shade/of blackness/from your hair, your self-') (Bhatt 1995, pp. 27, 32). With What the Water Gave Me: Poems after Frida Kahlo (2010), shortlisted for the T. S. Eliot Prize in the same year, Pascale Petit has brought much critical light to this ekphrastic following as part of Kahlo's cultural legacy. According to her author's note, the Poems explore how Kahlo 'used art to withstand and transform pain' and they are written in the voice of the painter and 'bear the titles of her paintings' (Petit 2010, p. 7). If Petit's What the Water Gave Me is a fictional autobiography in verse, Jay Griffiths' A Love Letter from a Stray Moon could be understood as a prosaic equivalent, yet restless in defying a clear-cut autobiographical, or biographical label ('I am Frida but also I am not Frida. I am her paintings [ ... ] I am many women'), or indeed any label ('choreography of my love, under a jaguar moon') (Griffiths 2011, pp. 27, 118).

Kahlo suffered a horrible bus accident which caused her pain throughout her life. Anticipating the sequential ekphrasis based on Kahlo by her contemporaries, Yoseloff's 'The Two Fridas', however, does not understand Kahlo's self-portrait of the same name $(1939)^{2}$ as a self-therapeutic means used to 'withstand and transform pain', or a pictorial manifesto for women, as in 'I am many women'. Rather, Kahlo's The Two Fridas is understood by Yoseloff as a projection of her feelings for her husband Diego Rivera, as suggested by the epigraph from Rivera: 'Frida tore open her chest and heart to reveal the biological truth of her feelings' (quoted in Yoseloff 1998, p. 51).

Basing on both Kahlo's painting and Rivera's account of Kahlo's art, Yoseloff's poem is voiced by one of The Two Fridas, who reveals that the other Frida is the opposite of her: 'I used to wear my heart on my sleeve/so he could see it beating, panting'; 'he was bored, so I churned out/a second girl', who 'looks just like his mother, all laced-up/and haughty' (Yoseloff 1998, p. 51). Continuing with the clothing metaphor implicit in the phrase 'wear my heart on my sleeve', the adjective 'laced-up' suggests the reticence of the 'second girl'. As it was Rivera's lack of interest in her which caused Yoseloff's Frida to create a double of herself, the poem also suggests that a 'laced-up/and haughty' persona could be more strategically effective than an 'open' 'heart' in this romantic relationship. We could also understand this as enacting two very different species of ekphrasis: recreating the surreal psychological drama portrayed in Kahlo's painting and describing an imaginary process of mechanically producing (as in 'churned out') a doppelgänger of oneself.

In The Two Fridas, Kahlo portrays herself in two versions: one in a traditional Mexican dress, and the other in European dress. The heart could be seen as split into two, with the heart in cross section for the Mexican Kahlo and a front view of the heart for her European counterpart. Such surreal image

2 See an image of the painting here: https://www.fridakahlo.org/the-two-fridas.jsp. 
informs Yoseloff's description of the halved heart-'I've split my heart/between us' (Yoseloff 1998, p. 51). The Mexican part of Kahlo in the self-portrait holds the hand of her European part, who is at risk of bleeding to death. Yoseloff describes them as 'linked/by hands' (Yoseloff 1998, p. 51) but does not allude to the two cultures Kahlo mediates. It seems that the speaker of the poem is based on the European Kahlo, whose dress has sleeves (as in 'wear my heart on my sleeve'), and whose heart, in cross section, is 'open'.

In What the Water Gave Me, Petit similarly includes a poem based on The Two Fridas, describing it as a 'double-self-portrait' of 'a bride with a strong girl/from the matriarchal Zapotec tribe' (Petit 2010, p. 42), and represents Kahlo's 'blood' as her 'paint' (Petit 2010, p. 43). Whereas Petit focuses on the process of Kahlo's transformation of her pain (represented by 'blood') into art (represented by 'paint'), Yoseloff does not allude to the dual cultures Kahlo foregrounds in her self-portrait. Rather, Yoseloff focuses on Kahlo's portrayal of her psychological struggle between wearing her heart on her sleeve and being 'all laced-up', which are her opposite, yet 'linked' personalities.

The heart as a central image, symbol and motif of Sweetheart is made clear by the title poem of the book. 'Sweetheart', as a note preceding the poem tells us, alludes to the story of Lady Devorgilla, who carried around the embalmed heart of his dead husband and who had his heart buried upon her own when she died (Yoseloff 1998, p. 26). The poem ends with a recreated voice of Lady Devorgilla describing the embalmment ('I took his heart, placed it in a [sic] ivory case') and declaring the use of the 'heart', the 'best' part of his dead body, as a reminder of his soul ('I have the best of him; even as the body/turns to dust, I tend his soul') (Yoseloff 1998, p. 27). The poem is ekphrastic in a sepulchral way. It describes the process of the widow's encasing the heart of her dead husband, and her use of the encased heart as a memento of 'his soul' or even equivalent to it, as if it were an objet d'art she keeps to herself, a boxed assemblage. This is, indeed, very different to John Keats' 'Ode on a Grecian Urn' from the ekphrastic canon, a poem glorifying the container of the ashes of the dead.

Ludwig Wittgenstein in Philosophical Investigations returns to exploring the distinction between our body and soul, and between our private thoughts and the revealing of them, asserting that 'The human body is the best picture of the soul' (Wittgenstein [1953] 1958, p. 178). Yoseloff's 'Sweetheart', where the widow uses the heart of her dead husband as a token of his soul, could be read in terms of Wittgenstein's idea. This encased 'heart' as the dead husband's 'soul' is, however, the opposite of Frida Kahlo's 'heart' being figuratively torn open as Rivera describes, or the 'heart' being worn on the sleeve by Yoseloff's version of Kahlo. It is an encased soul, of which the widow has made herself a keeper.

Wittgenstein's idea could, indeed, also be used to understand Kahlo's The Two Fridas and Yoseloff's descriptions of the painting and the mechanical making of a double which the painting could metaphorically represent. In Kahlo's painting, her two bodies serve as pictures of her wounded soul, as in the European body, and her self-healing soul, as in the Mexican body. In a comparable vein, Yoseloff's poem based on the painting similarly describes the heart as both a bodily organ and the seat of the emotions (as in 'I used to wear my heart on my sleeve' and later, 'I've split my heart/between us'). Following this line of thought, we could return to the epigraph from Rivera and understands it as meaning that the 'heart' represented in and by Kahlo's painting 'reveal[s] the biological truth of her feelings'.

In Philosophical Investigations, Wittgenstein also postulates that 'An image is not a picture, but a picture can correspond to it' and later argues that, 'The mental picture is the picture which is described when someone describes what he images' (Wittgenstein [1953] 1958, pp. 101, 115). While Wittgenstein uses words of pictorial art ('image' and 'picture') as metaphors for the distinction between our mind and our articulation of our thoughts, this also implies the capacity of art for presenting a version of ourselves. In 'The Two Fridas', the artist describes two expressions of her emotions, with one corresponding to her image, or her soul or 'heart'. We could also say that the poem itself is a complicated picture presented by the speaker, which narrates her inner conflict about how she manipulates her body into a picture of her own image.

With its iconography of clothing, beginning with the figurative image 'wear my heart on my sleeve', 'The Two Fridas' also invites a reading against psychoanalysts' similar uses of images of 
clothing to represent projection and inhibition of the self. Sigmund Freud in the fourth of his five lectures on psychoanalysis delivered in 1909 proposes that people rarely 'show their sexuality freely'; instead, they tend to 'conceal' it by wearing 'a heavy overcoat woven of a tissue of lies' (Freud 1962, p. 70). Rather than sexuality in modern day's usage, Freud means 'none of us can reveal his eroticism freely to others' (Freud 1962, p. 70). The British psychoanalyst Marion Milner in A Life of One's Own subsequently claims that 'my thought took to itself material from anywhere and everywhere in order to find a form in which to become clothed and visible' (Milner 1934, p. 171). In On Not Being Able to Paint, a further account of her own drawing as the basis of her theoretical work as an analyst, Milner similarly argues that her free drawings 'achieved the clothing of certain dreams with recognisable qualities of shape and colour' (Milner [1950] 2010, p. 139).

In Yoseoff's poem, Kahlo's creation of 'a second girl', who looks like 'his mother', could rest on Rivera's attachment to his mother and his possible projection of her onto Kahlo. This is also not 'girl' used as an intimate form of address to a female, as in my girl, and the word might instead refer to, as the online OED tells us, a maid or even a prostitute (OED Online 2019b). It is a complex and possibly eroticised model of herself Yoseloff's Kahlo imagines creating for pleasing her husband-a 'girl' looking like 'his mother', but as mentioned before, being 'all laced-up'. Yoseloff understands the images of the laces and sleeves in Kahlo's painting as symbols, like the Freudian symbol of the 'heavy overcoat', of the painter's expression and concealment of her desire for Rivera, the latter a strategy to win back in his interest in her. Recalling the psychoanalysts' returns to using images of clothes and the idea of clothing to represent the concealment of erotic desire or any thoughts and dreams, Yoseloff pays close attention to the images of clothing in Kahlo's painting and creates an extended metaphor based on clothes for two opposed ways of mediating erotic desire or romantic emotions: to 'wear my heart on my sleeve', or to be all 'laced-up'.

Speaking of laces, we should note that the image of 'laced-up' evokes the lace on Kahlo's dresses. With knowledge of Kahlo's The Two Fridas and her many costumes with lace, as in her self-portraits made in 1929, 1943 and 19483', 'laced-up' might also refer to the delicate fabric of her dresses with their elaborate pattern of holes, which is in stark contrast to its referring to tightly-fastened shoelaces. The image then paradoxically suggests both a whole-hearted and half-hearted attempt at reticence. It might, therefore, not be a Freudian 'heavy overcoat' the 'laced-up' persona figuratively wears. This paradox derived from the ambiguity of the poetic image makes the poetic speaker herself as 'laced-up' as the 'second girl' she is describing.

The tension between these opposite ways of handling her 'heart' or as the epigraph from Rivera tells us, 'her feelings' - candidly ('wear my heart on my sleeve') or reticently ('laced-up')—is carried on throughout the poem. We remember that the heart is split into two for the 'Two Fridas', yet they are 'linked/by hands'. The speaker's saying in the final stanza 'My half-heart is weak inside her' suggests that the speaker and her double are indeed one self split into two opposite personalities, experiencing a weakening ability to sustain the latter, her reticence (Yoseloff 1998, p. 51). As she goes on to say 'our heart/might thread together, I might grow/whole again', the double 'might' expresses doubt about a resolution to her split between openness and reticence (Yoseloff 1998, p. 51). The enjambments also give the poem a visual dimension as to its recreation of the splitting or cutting depicted in Kahlo's self-portrait, which the image of the pair of scissors dramatises. Adapting Kahlo's biography, Yoseloff reinvents the unresolved psychological drama surreally portrayed by Kahlo's The Two Fridas. Using figurative language and the poetic form, Yoseloff also recreates images of the body, in particular the heart, and clothing in Kahlo's painting to represent the body as a Wittigensteinian picture of the soul (or self), and to represent the dilemma for romantic or erotic thoughts to be, as Marion Milner says, 'clothed' or 'visible'.

3 See images of the self-portraits here: (1929) https://www.fridakahlo.org/self-portrait-time-flies.jsp; (1943) https://www. fridakahlo.org/self-portrait-as-a-tehuana.jsp; (1948) https://www.fridakahlo.org/self-portrait.jsp. 


\section{2. 'The Arnolfini Marriage': 'No One Will Ever Guess'}

'The Two Fridas' forms a pair with 'The Arnolfini Marriage' in Sweetheart. Both poems are based on paintings and bear their titles and like many poems in the book, explore the relationship of a married couple. 'The Arnolfini Marriage' is similarly an ekphrastic poem describing a painting and the creation of it. However, the first half of the poem is voiced by someone with knowledge of Jan van Eyck's The Arnolfini Portrait (1434) $)^{4}$ : 'Like Van Eyck's couple, so secure,/their backs to the mirror'; 'We can only believe/they were happy' (Yoseloff 1998, p. 30). Like Kahlo's The Two Fridas, which Yoseloff describes as a portrait of the two selves of the painter 'linked/by hands', van Eyck's The Arnolfini Portrait similarly depicts the husband holding his wife's hand. The hand-holding is indeed only a faint clue to how 'happy' 'Van Eyck's couple' are. While the poem says 'We can only believe/they were happy', we are also not given much clue to the relationship of 'Van Eyck's couple'. Perhaps this is a doubly ekphrastic study of a photographic image of a couple posing like 'Van Eyck's couple', thereby a kind of 'Arnolfini Marriage'.

Before this, the speaker expresses an urge to 'see the whole/picture', having a 'mirror' 'from a junk shop', which 'reflects/every inch of the room' (Yoseloff 1998, p. 30). What connects this situation with the study of the equivalent of 'Van Eyck's couple' is the similar portrayal of the 'mirror' as potentially an agent which can capture 'the whole/picture'. Conversely, the poem suggests that a mirror, in contrast to a painting, can give a fuller 'picture' of the self or selves. We can 'only believe/they were happy' in Van Eyck's painting. We do not, however, know this. The poem compares the 'Van Eyck's couple' to a couple looking like them, impressively bringing together Van Eyck's painting, the reflected image in a mirror and the figurative 'picture', as in the big picture or overall picture, and thus, multiplying the ekphrasis involved. However, the enjambments represent uncertainty about the capacity of mirrors to 'reflect/every inch of the room', or capture the 'whole/picture'. Even with the reflected image of a couple in a mirror, it is possible that 'We can only believe/they were happy'.

'The Arnolfini Marriage', like some other poems in Sweetheart, first appeared in the pamphlet Fun House (1994), Yoseloff's first book as a poet. The poem, in fact, gives the pamphlet its title: 'The artist himself/bears witness-his invention'; 'more fun house than honest' (Yoseloff 1998, p. 30). The poem has suggested that even a mirror only seemingly captures the 'whole/picture'; here, it proposes that a painting, and indeed any visual artwork (as in 'The artist'), is analogous to a fun house, perhaps with its distorting mirrors. This highlights the similar challenge faced by a mirror and an artist in telling the 'whole' truth, or being 'honest'. The second half of the poem continues to dwell on the suggestion that there is never a 'whole/picture' of 'Van Eyck's couple' by giving a discreet voice to the wife in Van Eyck's painting: 'I wore the green velvet, high-waisted, to hide my shame' (Yoseloff 1998, p. 30) This is a detailed description of the woman in the painting, an ekphrastic moment which ironically highlights the limit of ekphrasis in the form of prosopopoeia. Yoseloff could only read into the woman her 'shame', suggested by the woman wearing the 'green velvet, high waisted'. Yoseloff also dramatises the fact that the woman's thoughts remain 'clothed' by not explaining such 'shame' throughout the poem.

The painting is on display in the National Gallery, London and according to the gallery's website, the way the woman holds up her robe was fashionable at the time, but has often been mistaken as an indication of her pregnancy (The National Gallery 2019). Appropriating this controversy surrounding the painting, the second half of the poem is voiced by the pregnant-looking woman, who describes the process of her being instructed by the artist to 'hide' her 'shame':

The best artist in town,

hired to paint me in my gown,

took one look at me, grabbed a fold of my dress,

hold this up, like so ... no one will ever guess.

(Yoseloff 1998, p. 30)

4 See an image of the painting here: https://www.nationalgallery.org.uk/paintings/jan-van-eyck-the-arnolfini-portrait. 
Yoseloff brings the painter to the scene, who was beyond the frame of the painting, recreating the voices of the viewers, as in 'We', the woman in Van Eyck's painting, and even Van Eyck as in the italicised lines. The dress, as in 'The Two Fridas' is, again, described in terms of its function to figuratively clothe thoughts and feelings, this time, 'shame'. The folds of the dress are visually represented by the lines increasing in length, with the penultimate line slightly longer than the last one and hanging right above it. This is sonically highlighted by the couplets, especially 'dress' and 'guess'. Saying that 'no one will ever guess', the poem, however, ironically solicits our 'guess' of what is hidden beneath the 'dress'. The poem, like 'The Two Fridas', is both ekphrastic and an attempt to mimic the pictorial iconography using its poetic form. The poem is, again, a kind of textual picture itself, describing a painting and the creation of it and characteristically being a comparable picture printed on the page.

Paul Durcan in Give Me Your Hand (Durcan 1994), commissioned by the National Gallery, London, also has an ekphrastic poem based on the same painting through prosopopoeia. While the woman in Yoseloff's poem colludes with the painter to create an illusion about her, the couple in Durcan's poem say that 'Do not think you may invade/Our privacy because you may not' but describe the portrait of them as 'the most erotic portrait ever made' (11). The controversy surrounding the woman in van Eyck's painting has become a common subject of the ekphrastic poems based on it. Although the couple in Durcan's poem sternly reject any attempt to invade their privacy, they ironically call the portrait 'the most erotic', making us see van Eyck's painting as one and wonder how the representation of them could give a clue to their erotic desire. Yoseloff similarly foregrounds the impenetrability of 'privacy', but she is only concerned with the woman's and does not cast much light on the hidden 'shame'.

\subsection{Photographs, Sculpture and 'The Visible Man': 'Until I Can Open the Door to My Heart'}

Yoseloff's fascination with the representations of the concealed (or 'clothed') self in the visual arts pervades the book Sweetheart. In 'The Arnolfini Marriage', Yoseloff understands the artist as a 'witness' to the truth about the married couple and explores the relationship between the painter and his subject. Elsewhere, Yoseloff expresses a similar understanding of photographers and photographic images. 'King and Queen' brings together a photograph of the speaker's parents and Henry Moore's sculpture of the same name of the poem ${ }^{5}$. The faces of 'Moore's King and Queen' are described as 'complicated', their 'hands not quite touching', while the photographic image of the parents is similarly given a detailed descriptive account, ending on what it does not capture: 'In the foreground they are separated by table'; 'What connects them cannot be seen' (Yoseloff 1998, p. 29). Yoseloff continues to explore the visible, or invisible connection between two subjects (or two halves of a subject), as in a painting, photograph and sculpture.

In 'The Loved Ones', Yoseloff similarly sees the photographer as an 'artist' but understands his or her role of capturing 'souls' as 'not easy': 'It's not easy/to capture souls from photos, but an artist/must see the things that are invisible' (Yoseloff 1998, p. 33). Indeed, even though Wittgenstein argues that 'The human body is the best picture of the soul', the lack of a bodily connection, as in Moore's King and Queen and the photograph of the parents, does not give a sense of how the two pairs are married couples. Their faces could look 'complicated' (as in 'my mother offers her profile, gazes somewhere/out of frame') and their souls remain 'invisible' to the speaker and to us (Yoseloff 1998, p. 29). It is the same impossible challenge of trying to 'see the things that are invisible' which faces 'an artist' and a viewer of a visual artwork. In 'The Box', the 'publicity shot' of the novelist uncle, looking like 'a young Steinbeck', is again, seen as unfamiliar: 'I never knew you like this:/that first flush of success, that double-breasted suit' (Yoseloff 1998, pp. 44, 45). The visible, as in a 'publicity shot' of a man in his suit, it seems, always clothes the invisible.

I want to end my discussion of Sweetheart with 'The Visible Man', where the exploration of our heart and the visibility of a subject captured in a visual artwork or artefact is the most forthright.

5 See an image of the sculpture here: https://www.tate.org.uk/art/artworks/moore-king-and-queen-t00228. 
Indeed, the title already plays antithetically on that of Ralph Ellison's Invisible Man, foregrounding such questions of exposure. The poem distinctly describes the hands-on use of a model of a man, as opposed to a distanced looking at a sculpture as in 'King and Queen'. The poem addressing a miniature man begins as a detailed examination of the model, in particular, its heart: 'The Visible Man' 'displays his arteries and veins to me/like a road map. I trace the tangled route/to the heart, encased in plastic' (Yoseloff 1998, p. 25). Whereas the 'arteries and veins' are displayed, 'the heart' is 'encased in plastic', like the one placed in an ivory case in 'Sweetheart'.

Although the 'man in miniature' only shows 'his arteries and veins' and an encased heart, the model is used to satisfy the speaker's desire 'to understand/everything: the flow of blood and semen,/the beat of the pulse' and why all the men she has known 'snapped shut eventually when faced with the prospect of love,/of a woman right in front of him' (Yoseloff 1998, p. 25). The miniature is described as a kind of 'man in miniature', with an imaginary life. It is a replica onto which all the men the woman has known are projected and one which represents the body of all men, serving as a Wittigensteinian picture of their vitality ('the flow of blood'; 'the beat of the pulse') and prominently, their sexual desire (the flow of 'semen').

The model of a man, with 'his arteries and veins', is interestingly compared to 'a road map', a two-dimensional pictorial representation. The model is, however, only used to 'trace the tangled route/to the heart', revealing that it is 'the heart' (not his heart) the speaker hopes to fully understand. Indeed, the woman later says:

[... ] I must be content with this model of a man, a training kit,

until I understand what makes me tick, until I can open the door to my heart, the way I can lift his breastplate up, and watch myself in motion, the same veins and arteries, the same blood.

(Yoseloff 1998, p. 25)

We now know that the 'model of a man' is perhaps in the costume of a knight, with 'his breastplate'. As she can lift up the breastplate, this knight-model is, unlike all the men she has known who 'snapped shut' before a romantic relationship began, all-visible to her. We remember that 'the heart' is 'encased in plastic'. The woman, indeed, does not dwell on the male heart but uses the 'model of a man' as 'a training kit' until she 'can open the door to [her] heart'. The woman in 'The Arnolfini Marriage' leaves us to wonder what kind of shame she is hiding in her dress, but van Eyck's painting, the pictorial reference, has made us guess that the woman is pregnant (though she is not). However, the woman, in stark contrast to 'The Visible Man', remains a kind of invisible woman. After understanding the model as representative of the men she has known, she strangely sees in it herself 'in motion'. The 'man in miniature' and the woman could indeed be largely 'the same', both with 'the flow of blood', except for the flow of 'semen'. The poem eerily explores the woman's identification with a model of a man, as if she were similarly a model. If the poem is voiced by Yoseloff, we could as well say she has subjected herself to her own ekphrasis, describing herself as projected onto a model. As the woman's heart remains figuratively locked or 'encased' to herself, the poem dramatises the fact that our heart, as what governs the way we 'tick', is like the heart as our organ, not easily visible, and even to ourselves.

\subsection{Conclusions: 'What's at the Heart of My Heart?'}

As said before, The City with Horns, Yoseloff's fourth collection, includes a series of poems about the American painter Jackson Pollock in the wake of his poetic contemporary Frank O'Hara. To conclude, I want to suggest that $\mathrm{O}^{\prime}$ Hara is a potential inspiration for the many hidden hearts in Sweetheart. In 'The Heart', a self-conscious poem (as in 'That's/not like Frank!'), O'Hara describes his creation of an image of himself through wearing different clothes, often a rebellious image: 'I/don't wear brown 
and grey suits all the time'; 'I wear workshirts to the opera,/often' (O'Hara 1995, p. 231). This is like Yoseloff returning in Sweetheart to describing images of clothes as the means to achieve a kind of invisibility of our selves. Saying 'you can't plan on the heart, but/the better part of it, my poetry, is open' (O'Hara 1995, p. 231), O'Hara also understands his poetry as a representation of the 'better part' of the heart and conversely suggests that his heart is not 'open'. In 'A Step away from Them', O'Hara makes a similar assertion about his heart, clothes and poetry, 'My heart is in my/pocket, it is Poems by Pierre Reverdy' (O'Hara 1995, p. 257).

The poems in Yoseloff's Sweetheart are, like O'Hara's poetry, often 'open' to our interpretation as to the secrets of the speakers or the subjects depicted in visual artworks. There are the hidden shame of the woman recreated based on van Eyck's painting, the unseen connection of the parents in a photograph, and the invisible heart of the woman as opposed to 'The Visible Man'. Yoseloff's Sweetheart also revolves on the heart in many senses, referring to the biological heart, the endearment 'Sweetheart', as well as our feelings (as in 'wear my heart on my sleeve'), our soul (as in the dead husband's heart as 'his soul') and what makes us 'tick'.

As a whole, Sweetheart enacts a group of ekphrastic descriptions of visual artworks concerning the reception and creation of them. The book also balances two opposite psychological dynamics: the desire to probe into someone's heart and the struggle to 'bare' one's heart, which awaits coming into full existence. In fact, this is anticipated by the pamphlet Fun House, in which 'The Arnolfini Marriage' and 'The Loved Ones' first appeared. In 'The Clifton Suspension Bridge, Bristol', Yoseloff asks 'What's at the heart of my heart?/No hand of man or science/can touch, the camera/obscura' (Yoseloff 1994, p. 7). Moving on from her obsession with the heart represented in visual artworks and artefacts and represented using images of art (as in 'the camera/obscura') or even heart itself (as in 'the heart of my heart') as metaphors, Yoseloff still dwells on various kinds of enigmatic autobiographical and biographical representations in art. As mentioned before, she has described Cy Twombly as a 'Cryptographer' and calls his art as created in 'a language no one understands'. We could now compare his incomprehensible 'language' to her own poetic language. Following in the footsteps of Frank O'Hara and even Cy Twombly among others, Yoseloff has turned herself into an important figure in the ongoing tradition of poetic ekphrasis and distinctly, an ekphrastic cryptographer by exploring and recreating the tension between concealment and revelation represented in art.

Funding: This research received no external funding.

Acknowledgments: I am grateful to Hugh Haughton at the University of York for his invaluable feedback on the original conference paper from which this article has developed.

Conflicts of Interest: The author declares no conflict of interest.

\section{References}

Bhatt, Sujata. 1995. The Stinking Rose. Manchester: Carcanet Press.

Durcan, Paul. 1994. Give Me Your Hand. London: Macmillan London Ltd. \& National Gallery Publications.

Freud, Sigmund. 1962. Two Short Accounts of Psycho-Analysis. Edited and Translated by James Strachey. Harmondsworth: Penguin Books.

Griffiths, Jay. 2011. A Love Letter from a Stray Moon. Melbourne: The Text Publishing Company.

Loizeaux, Elizabeth Bergmann. 2008. Twentieth-Century Poetry and the Visual Arts. Cambridge: Cambridge University Press.

Milner, Marion. 2010. On Not Being Able to Paint. New York: Routledge. First published 1950.

Milner, Marion. 1934. A Life of One's Own. London: Chatto \& Windus.

O'Hara, Frank. 1995. The Collected Poems of Frank O'Hara. Edited by Donald Allen. Berkeley: University of California Press.

'ekphrasis, n.'. 2019a. OED Online. Available online: http://www.oed.com/view/Entry/59412 (accessed on 15 March 2019).

'girl, n.'. 2019b. OED Online. Available online: www.oed.com/view/Entry/78475 (accessed on 15 March 2019).

Petit, Pascale. 2010. What the Water Gave Me: Poems after Frida Kahlo. Bridgend: Seren. 
'The Arnolfini Portrait'. 2019. The National Gallery. Available online: https://www.nationalgallery.org.uk/paintings/ jan-van-eyck-the-arnolfini-portrait (accessed on 15 March 2019).

Wittgenstein, Ludwig. 1958. Philosophical Investigations. Translated by G. E. M. Anscombe. Oxford: Basil Blackwell, First published 1953.

Yoseloff, Tamar. 1994. Fun House. London: Slow Dancer Press.

Yoseloff, Tamar. 1998. Sweetheart. London: Slow Dancer Press.

Yoseloff, Tamar. 2011. The City with Horns. London: Salt Publishing.

Yoseloff, Tamar. 2013. Invective against Swans. Available online: https://www.tamaryoseloff.com/blog/invectiveagainst-invective (accessed on 15 March 2019).

Yoseloff, Tamar. 2015. A Formula for Night: New and Selected Poems. Bridgend: Seren.

(C) 2019 by the author. Licensee MDPI, Basel, Switzerland. This article is an open access article distributed under the terms and conditions of the Creative Commons Attribution (CC BY) license (http://creativecommons.org/licenses/by/4.0/). 